\title{
電動ベッドに後付け可能な起立支援機器の提案*
}

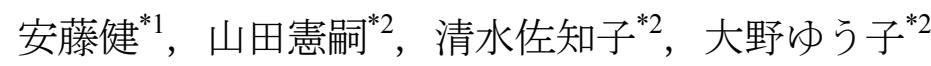

\section{An Attachable Standing-Assist-Robot to Motorized Bed} \\ Takeshi ANDO*1 , Kenji YAMADA, Sachiko SHIMIZU and Yuko OHNO \\ ${ }^{*}$ Osaka University, Dept. of Robotics \& Design for Innovative Healthcare (Panasonic), Graduate School of Medicine \\ 1-7, Yamada-oka, Suita, Osaka, 565-0871 Japan
}

We propose and develop a standing assist robot, which is attachable to the motorized bed, for the elder at hospital or home. Especially, the target user of the robot is the elder who can walk indoor independently, but can not stand up because of his or her muscle strength ability. The developed robot has three degree of freedoms (two active joints for rotation and translator and one passive joint for the rotation) which promote trunk's forward tilting and elevate the center of gravity by assisting to extend the knee and hip joints. We confirm that the developed system is attachable to the typical motorized bed using the space under its bed. The myoelectric signals of Tibialis Anterior (TA), Rectus Femoris (RF) and Erector Spinae (ES) are measured to analyze the effectiveness of the developed standing assist robot. As a result, the myoelectric signals of TA, RF and ES with using the developed system are about from twice to three times smaller than those in normal standing. In addition, the myoelectric signals of RF and ES are the almost same as those during the walking. In other word, it is confirmed that the burden for the muscle is suitable, because the target user can walk and can not stand up. Therefore, this result shows the effectiveness of the proposed concept and developed prototype that the robot is attachable to the bed.

Key Words : Medical and Welfare Assistance, Welfare Engineering, Nursing Engineering, Standing

\section{1. 緒言}

世界中で高齢化が顕著に進む中で，高齢者に対する在宅や病院における看護および介護の二ーズが非常に大き くなっている，限られた看護師および介護者の支援の中で，高齢者の QoL を最大限に向上させるためには，高齢 者の自立生活，特に自立移動の獲得が重要である．特に，病院や介護施設など室内での移動を考えると，自立歩 行獲得の意義は非常に大きい.ただし，歩行動作を行う前には多くの場合において起立動作を伴うこと，歩行動 作よりも起立動作の方が下肢への負担が大きいこと，を考慮すると，自立的に起立を行う能力も強く必要とされ ている. 特に，病院でのリハビリ期間が短縮化されている現状においては，在宅など施設内でのべッドからの起 立動作に関するニーズが存在している.

起立動作を支援する機器として最も使われているのが，手すりや歩行器などである．これらは，低価格で設置 もしやすく，汎用性が高いという利点がある。しかし，実際に手すりや歩行器の使用中における転倒も報告され ており，安全性の面で優れているとは言い難い。このような背景から多くの起立支援ロボットの研究開発が進め られている. 山田らは, 椅子からの起立支援を目的として, 椅子座面自体が可動するシステムを開発している(1). また，ベッドからの起立を対象としたものとしては，中後ら (2)や山口ら ${ }^{(3)}$ は，歩行器と起立支援機を組合せたシス

\footnotetext{
* 原稿受付 2011 年 10 月 9 日

*1 正員, 大阪大学 大学院医学系研究科ロボティクス\&デザイン看工融合 (Panasonic) 共同研究講座 (干565-0871 大阪府吹田市山田丘 1-7)

*2 大阪大学 大学院医学系研究科保健学専攻

E-mail: takecando@gmail.com
} 
テムを開発し，起立支援と歩行支援を両立したシステムを開発している．初雁らは，ベッド側方に設置したバー の運動により前傾誘導を行うなど理学療法士による起立支援技術が模擬できるような機器を開発している(4).

これらのシステムは高い起立支援能力を有しているが，新たな設置空間もしくは使用空間を必要と寸る．病室 などは既に多くのものが詰め込まれており，狭小な空間となっていることが多いので，このようなシステムを効 果的に使うことが難しく，現場への普及が限定的となっている.

そこで，本研究では既存の空間を最大限に活用することで新たな使用空間を必要としないべッドからの起立支 援機器を開発することを目的とする.

本論文では，第 2 章において開発する起立支援機器を使用する対象について説明し，第 3 章では起立支援機器 のコンセプトおよび開発要件を述べる.さらに, 第 4 章において開発したプロトタイプの機構系, 電気系, 制御 系について詳述し, 第 5 章において健常者による起立支援機器の評価を筋負担の観点から実験・解析寸る. 最後 に, 第 6 章において結論と展望を述べる.

\section{2. 機器の使用シーンおよび使用者の設定}

本研究では，在宅や病院などで自立歩行は可能であるが，自立起立が困難である高齢者が，在宅や病院などで 電動ベッドから起立するシーンを支援対象とする.

高齢者が立ち上がり動作を行えなくなる理由の 1 つに, 下肢筋力の低下が挙げられる(5).これは立ち上がり動 作が歩行動作などとは異なり重力に抗する運動であり, 下肢の伸展による体重心の上方移動に最も筋力が必要と なるからである，立ち上がるのに必要となる関節モーメントは下肢股関節，膝関節で 200[Nm]弱とされており， 歩行の数 $10[\mathrm{Nm}]$ と比較すると非常に大きく, 負荷の高い動作であることがわかる(6). ただし, 下肢の伸展動作は

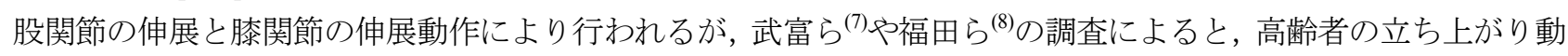
作可能群と不可能群の股関節伸展力に有意差はないと報告されている. 一方, 大森ら ${ }^{(9)}$ は, 膝の伸展力が高齢者 の立ち上がり動作の可否に大きく関わっていることを示している. これは身体上方移動に最も関与するのが膝関 節の伸展であることが原因であると考えられる(10). また, 膝伸展筋群の 1 つである大腿四頭筋が動作の最大の制 限因子となっているという報告とも一致する ${ }^{(11)}$. さらに, 江原ら ${ }^{(12)}$ にれれ゙，臀部離床動作時に膝関節負荷が 最も大きくなるので, 膝の伸展に関する筋力が剧部離床に必要な筋力より大きいことが起立可否に大きく関わ っていると言える.

高齢者の膝伸展力と起立可否および歩行可否の関係については, 大森らが高齢入院患者を対象とした研究を行 っている ${ }^{(13)}$. 歩行に関しては, 等尺性膝伸展筋力が $0.25[\mathrm{~kg} / \mathrm{kg}]$ (これ以降, 起立などに必要な膝筋力や膝モ一メ ントは体重に強く依存するので, 体重で正規化した值を用いて議論することとする.）以上の全ての患者が室内歩 行可能となっている ${ }^{(14)}$. 一方, 起立に関しては, 膝伸展筋力が $0.30 \sim 0.34[\mathrm{~kg} / \mathrm{kg}]$ の患者の 9\%, 0.25 0.29[kg/kg]の 患者の $37 \%$ が $0.40[\mathrm{~m}]$ からの起立が不可能とされている. これらの文献の各膝伸展筋力における起立可否および 歩行可否の割合から算出すると, 高齢者入院患者の $7.5 \%$ は, 歩行は可能であるが起立が不可能であることになる. さらに, 在宅や施設で生活をしている高齢者を考慮すると, 本支援機器が適応可能となる使用者は更に多くなり, 本研究で開発を目指寸「自立歩行は可能であるが自立起立が困難である高齢者の, 在宅や病院などにおける電動 ベッドからの起立支援機器」の意義は非常に大きい.

\section{3. 起立支援機器の開発要件}

1 章で述べた目的を踏まえ，本研究で開発する起立支援機器の開発要件を以下の 3 点とする.

（1）既存の電動ベッドに後付け可能であること

(2) 既存の病室空間を阻害しないこと

・現在，電動ベッドの下の空間がデッドスペースとなっているので，機構部分および電装部分の多くがベッ ド下空間に収納できるようにする. 


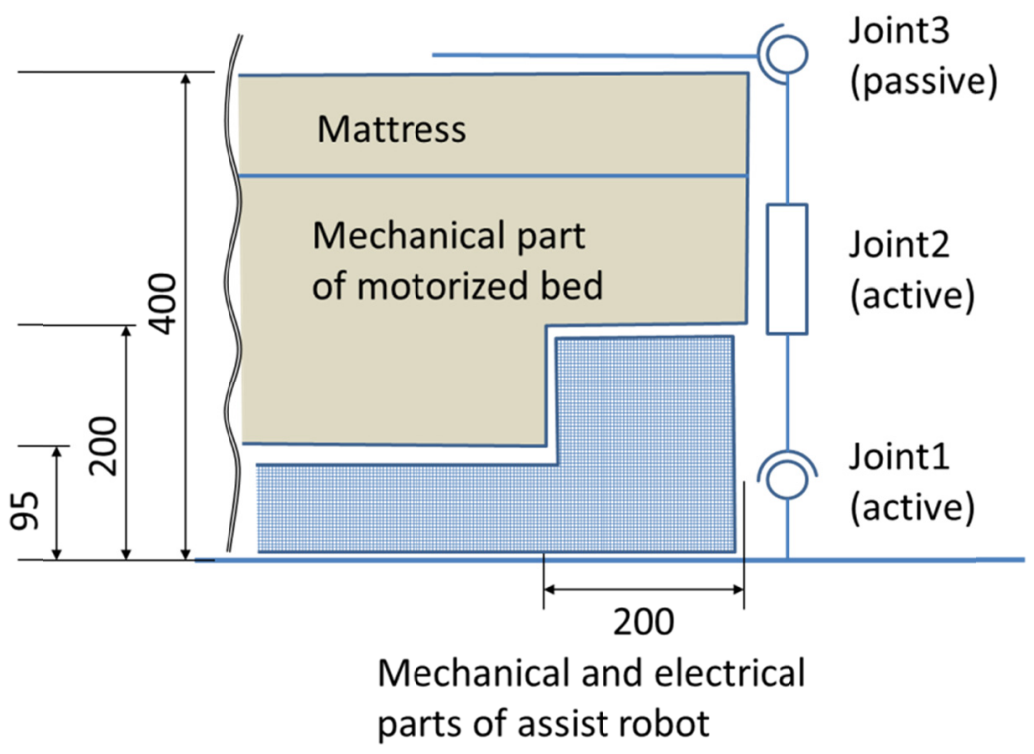

Fig. 1 Space under the motorized bed and concept of the developed standing assist robot

・大阪大学医学部保健学科などで実習用に用いられている一般的な電動ベッド (パラマウント社製) のベッ ド下空間寸法を計測したところ図 1 のよであった.

（3）強引に起立させるのではなく，理想的な起立を誘導すること

・紙屋 ${ }^{(15)}$ により患者の残存機能を活用する起立方法が提案されているが，一般的な看護師および介護士によ る起立支援においては，腰痛防止などの理由により支援する側のボディメカニクスを考慮する必要がある ため，必ずしも患者側に最適（下肢の関節モーメントが最小となる）な起立とはならない，一方，機器を 用いる場合には患者側が最も起立を行いやすいキネステティックの起立方法を実現できるので，患者の残 存機能を効果的に活用できる機器システムとする.

・起立時に最大の負荷となる膝関節モーメントを減少させるように上体を前傾し，膝伸展・股関節伸展によ り慰部の離床，さらには重心を上昇させる(2)

・前傾誘導のための 1 自由度，重心上昇のための 1 自由度を有する.

（4）移動性があること

・キャスタ設置により移動性を確保する．ただし，固定時には支援機器が動かないようにする.

\section{4. プロトタイプの開発}

図 2 に開発した起立支援機器のプロトタイプを示した。 また，図 3 に示したように電動ベッドに後付け可能で あることを確認した。

\section{$4 \cdot 1$ 機構系}

開発した起立支援機器の自由度は全体で 3 自由度とし，能動関節 2 つ受動関節 1 つから構成される. 前傾を 誘導する動作は，アクチュエータ 1 を 2 並列にし，直動により関節 1 （可動域：0４5 deg）を回転させること で行うこととした. 関節 1 の回転角度はロータリーエンコーダ (ムトウエンジニアリング, UN360, 分解能 $0.5 \mathrm{deg}$ ) により取得した．また，使用者の慰部を持ち上げる動作は，アクチュエータ 2 の回転をタイミングベルトにより ボールネジ（ストローク $298 \mathrm{~mm} ，$ リード $10 \mathrm{~mm}$ ） に伝達し，関節 2 を直動させることで行うこととした．これに より高さは 400〜800mm の範囲で上下動する，一方，関節 3 はパッシブとし，着座するとストッパーが外れ，ス

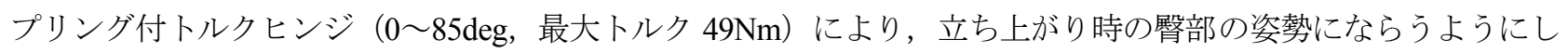
た. 全体重量は $25 \mathrm{~kg}$ となった. 表 1 , 表 2 に使用したアクチュエータ 1 およびアクチュエータ 2 の仕様をそれぞ れ示す. 


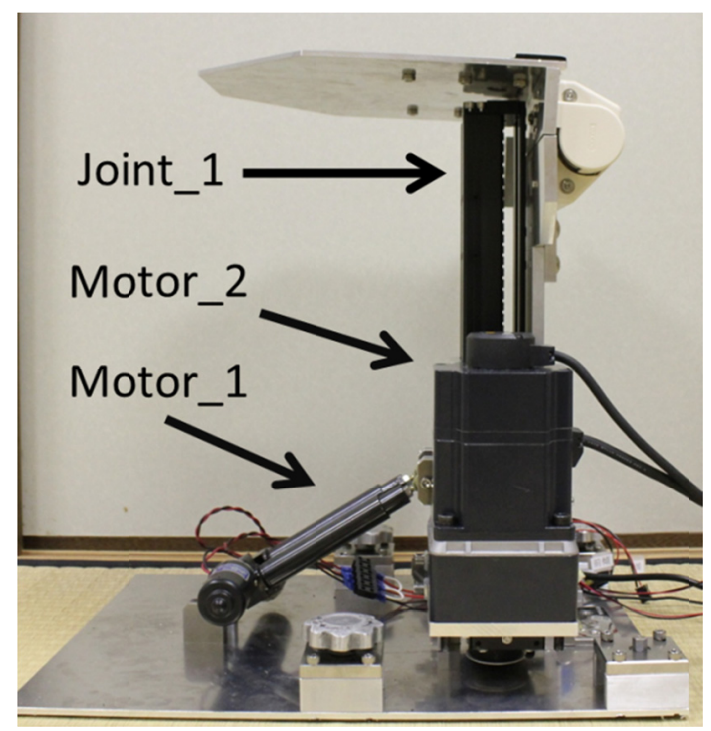

(a) Side view

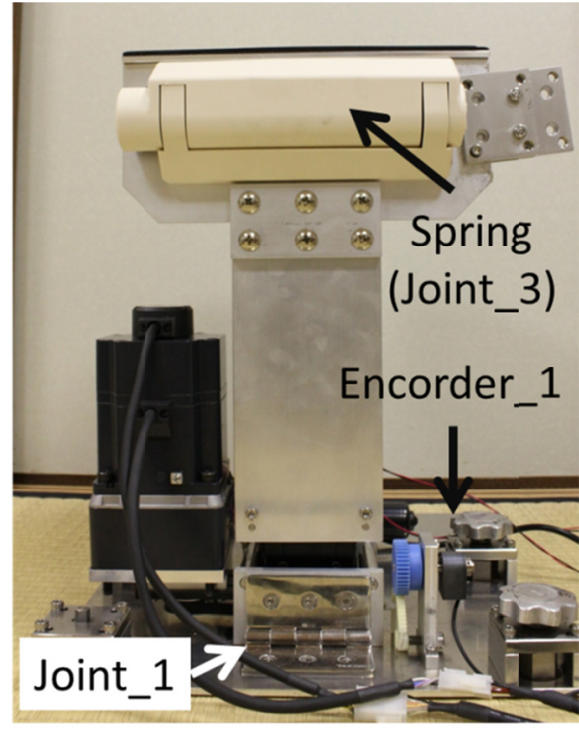

(b) Front view

Fig. 2 Prototype of developed standing assist robot

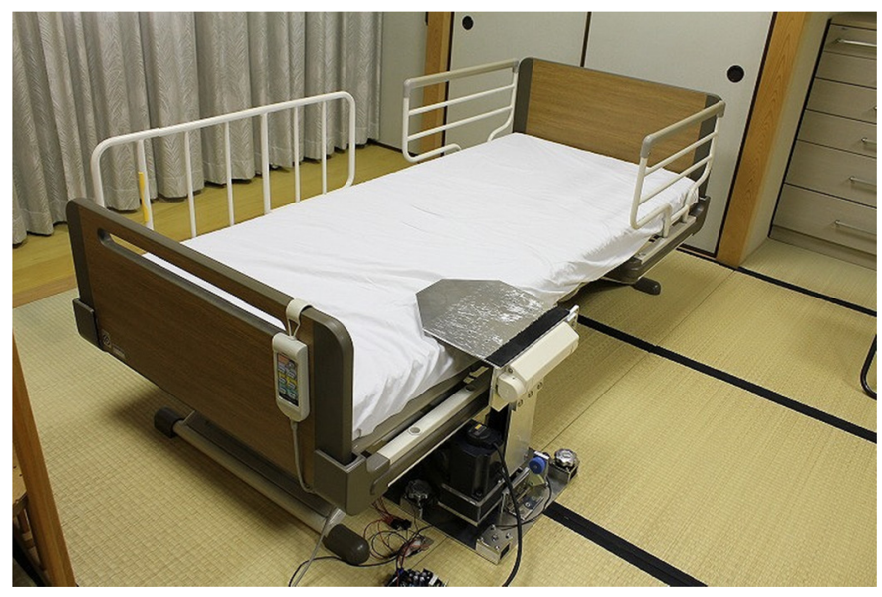

Fig. 3 Attachable robot to the motorized bed

Table 1 Specification of motor for forward tilting

\begin{tabular}{|c|c|}
\hline Product maker & Tokusyu Motor \\
\hline Output $\mathrm{W}$ & 8 \\
\hline Maximum axial thrust force kgf & 40 \\
\hline Rated rotational velocity rpm & 7500 \\
\hline Reduction ratio & $1: 30$ \\
\hline Stroke of slide $\mathrm{mm}$ & 100 \\
\hline
\end{tabular}

Table 2 Specification of motor for elevating

\begin{tabular}{|c|c|}
\hline Product maker & Oriental motor \\
\hline Output $\mathrm{W}$ & 200 \\
\hline Rated toruque $\mathrm{Nm}$ & 0.65 \\
\hline Rated rotational velocity $\mathrm{rpm}$ & 3000 \\
\hline Reduction ratio & $1: 5$ \\
\hline
\end{tabular}




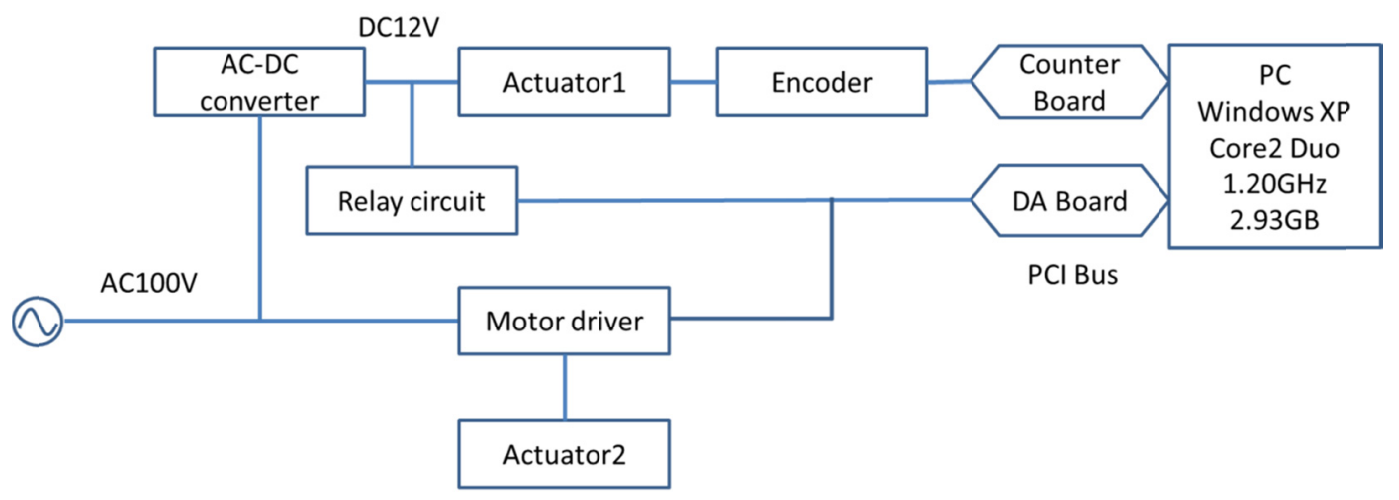

Fig. 4 Electrical system

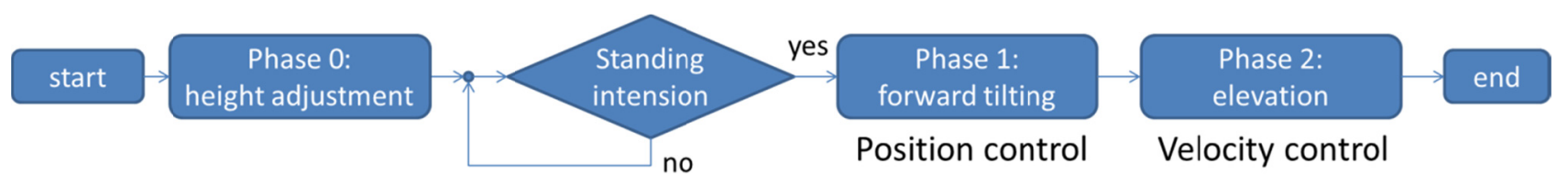

Fig. 5 Control flow chart

\section{$4 \cdot 2$ 電気系}

電気系のシステム構成を図 4 に示した.アクチュエータ 1 は角度制御を行った. エンコーダ值は PCI バス形式 のカウンターボードにより PC に入力され, DA ボードにより電源 $12 \mathrm{~V}$ のインチングにより制御を行った. アク チュエータ 2 は，モータドライバからエンコーダ值を読み込み，DA ボードを介した速度指令に基づいて速度制 御を行った.

\section{$4 \cdot 3$ 制御系}

開発した起立支援機器の制御フローを図 5 に示した.

まず，Phase 0 として，支援機器の座面高さが事前に計測した使用者の膝下高さと等しくなるようにし，膝の角 度が約 90[deg] となるようにした。 その後，3章で述べたように本機器はあくまでも起立の意志がある人が身体負 担を抑えながら起立することを支援するため，使用者に起立の意志があることを確認し，実際の起立支援に移行 する，ただし，自ら少し体幹を前傾し，座面にかかる負荷が閾值より小さくなった場合に，起立の意図があるも のとした．例えば，高齢者の平均体型 ${ }^{(16)}$ （57[kgf]）の人が図 6 に示した座位の状態から起立したとき，アクチュ エータ 1 の推力 $f_{\text {actuatorl }}=80[\mathrm{kgf}]$, 角度 $\theta_{\text {actuatorl }}=28.3[\mathrm{deg}]$, 座面端から股関節までの距離 $l_{\text {chair_hip }}=210[\mathrm{~mm}]$ から図 7(a) に示したのモデルにおける支援機のモーメント釣り合いより，座面にかかる力が 47[kgf]（つまり，足裏にかかる 力が 10[kgf]）となったときに，起立の意志を確認し，Phase1 に移行するものとなる.

Phase 1 ではより膝への負荷を軽減するために, 更に前傾を促すように関節 1 を回転させた. 中後ら (2)によると, 立ち上がる人が不安定にならない範囲でできる限りで前傾をさせた方が良い. 被験者 2 名に対して前傾角度のみ を20[deg]まで変化させる予備実験を行ったところ, 前傾が 7[deg]以上になると, 足裏で強く踏ん張る必要がある こと，また前に落ちそうな不安を感じることがわかった。これより7deg 以内であれば，不安を感じることなく， また意図的に座位状態を保つ必要がなく, 前傾が可能であったので, Phase 1 においては7[deg]まで前傾を誘導し, 体の重心が足底面に近づくようにした．このときはエンコーダ值を用いて，角度制御を行う。

さらに, Phase 2 においては，足底面に近づいた重心の高さを上昇させるために，アクチュエータ 2 を速度制御 した．速度指令值は高齢者の起立速度と安全性を考慮し， $50[\mathrm{~mm} / \mathrm{s}]$ とした．ただし，最大上昇幅は事前に計測し た大腿部長さとし，起立したときに臀部付け根にパッシブ関節である関節 3 がくるようにした．また，特に Phase 2 の後半において足底に体重のほとんどが移行すると, 関節 3 の復元力により, 臀部が軽くもちあがるようにし た. Phase 2 において, 関節 2 が直動するレール部の上端, 下端に設置したリミットスイッチによりアクチュエー タ 2 を停止させた。 


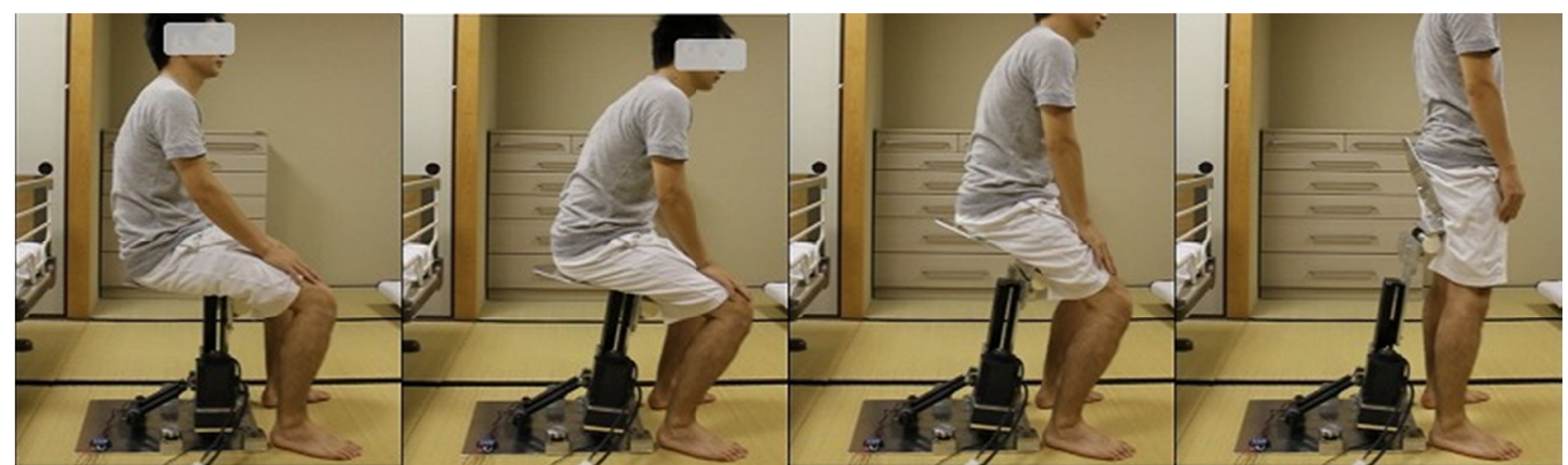

(a) start

(b) forward tilting stop

(c) elevating

(d) standing

Fig. 6 Movements of human and assist robot

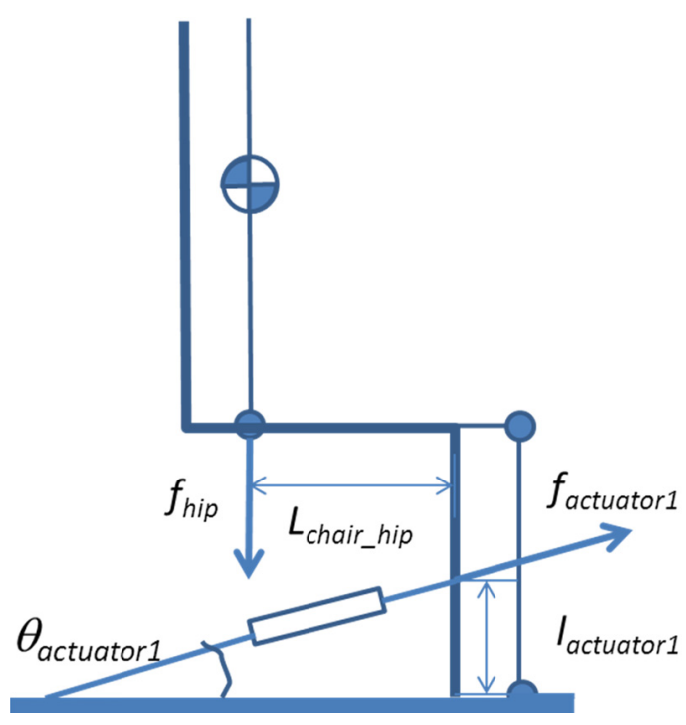

(a) Estimation of hip contact force

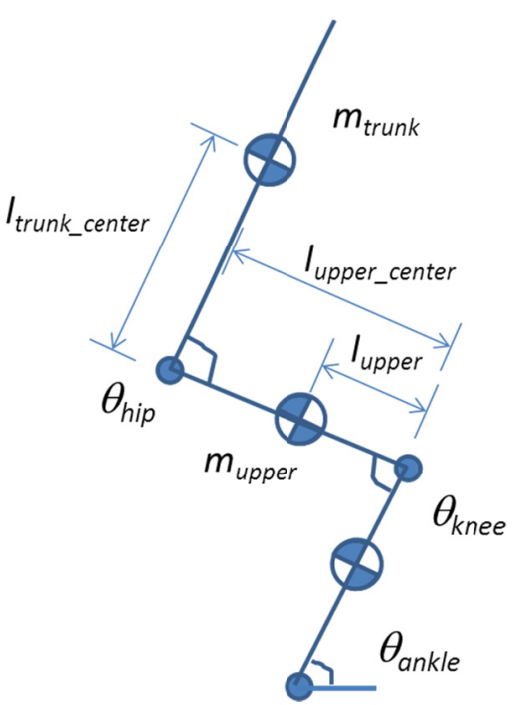

(b) Estimation of knee joint moment

Fig. 7 Rigid links model of standing human

各 Phase におけるモータの制御をまとめると以下のようになる.

Phase 0（座面高さ調整）：アクチュエータ 2 の回転による関節 2 の直動による垂直持ち上げ

Phase 1（前傾誘導）：アクチュエータ 1 の伸展による関節 1 の回転により前傾（位置制御）

Phase 2（重心上昇）: アクチュエータ 2 の回転による関節 2 の直動による前方への持ち上げ（速度制御）

図 6 に起立支援時の人と機器の動きを示した。ただし，動きがわかるようにするために，機器はベッドから取 り外し，機器単体で使用した． (a)が高さ調整後の姿勢であり，(b)が前傾 7deg での様子であり，体幹が前傾し， 頭部位置は(a) と比較すると大きく前方に移動していることが確認できた，その後，(c)でアクチュエータ 2 が駆動 し，重心を上昇させ，最後の(d)ではパッシブ関節 3 の復元力により軽く慰部が押し出されている.

ここで，起立動作で最も困難な臂部離床時の膝関節モーメントを推定する．人体を図７のような足，下腿，上 腿, 胴体から構成される 4 剛体リンクモデルで考えると, 体重で標準化された膝関節周りのモーメント $M_{\text {knee }}$ $\mathrm{Nm} / \mathrm{kg}$ は,

$$
\begin{aligned}
M_{\text {knee }}= & \left(m_{\text {trunk }} / m_{\text {total }}\right) g\left(l_{\text {upper }} \cos \left(\theta_{\text {knee }}-\theta_{\text {ankle }}\right)-l_{\text {trunk_center }} \cos \left(\theta_{\text {hip }}-\theta_{\text {knee }}+\theta_{\text {ankle }}\right)\right) \\
& +\left(m_{\text {upper }} / m_{\text {total }}\right) g l_{\text {lupper_center }} \cos \left(\theta_{\text {knee }}-\theta_{\text {ankle }}\right)
\end{aligned}
$$


Table 3 Mass and length of rigid link model to simulate normal elder

\begin{tabular}{|c|c|}
\hline$m_{\text {trunk }} \quad \%$ & 58.8 \\
\hline$m_{\text {upper }} \quad \%$ & 9.2 \\
\hline$l_{\text {upper }} \quad \mathrm{mm}$ & 386 \\
\hline$l_{\text {trunk_center }} \quad \mathrm{mm}$ & 464 \\
\hline$l_{\text {upper_center }} \mathrm{mm}$ & 200 \\
\hline
\end{tabular}

という式で表される.

ただし， $m_{\text {trunk }}, m_{\text {upper }} m_{\text {total }}$ は胴体部，上腿部，全身の質量， $l_{\text {upper }}, l_{\text {trunk_center }}, l_{\text {upper_center }}$ は上腿長さ，股関節中心から 胴体部重心までの長さ, 膝関節中心から上腿部重心までの長さ, $\theta_{\text {hip, }}, \theta_{k n e e,} \theta_{\text {ankle }}$ は股関節角度, 膝関節角度, 足関 節角度, $g$ は重力加速度とした.

また，本推定では，起立は平均的体型の高齢者の静的起立動作とするという仮定を設ける．表 3 に示した文献 (16)から算出した高齢者の平均体型, 文献(17)から算出した高齢者の平均リンク長, リンク重心位置, リンク質量 および，図 7 から算出した関節角度 $\left(\theta_{h i p}=63 \mathrm{deg}, \theta_{k n e e}=86 \mathrm{deg}, \theta_{\text {ankle }}=89 \mathrm{deg}\right)$ を用いて膝負担を算出すると, 体重 で標準化した膝関節モーメントは $1.13 \mathrm{Nm} / \mathrm{kg}$ となる. $\theta_{\text {hip }}=90 \mathrm{deg}, \theta_{\text {knee }}=90 \mathrm{deg}, \theta_{\text {ankle }}=90 \mathrm{deg}$ となる通常座位姿勢か ら臀部離床を行ったときの膝関節モーメントは $2.40 \mathrm{Nm} / \mathrm{kg}$ となるので, もし前傾誘導後に重心上昇機能を使用せ ず, 自力で慰部離床する場合においても, 膝への負担を約 53\%軽減できることになる. 蛭田ら ${ }^{(18)}$ によると 70 歳 代の健常高齢者男性の膝伸展卜ルクは約 $1.7 \mathrm{Nm} / \mathrm{kg}$ であるので, 健常高齢者の場合はPhase1 のみの支援で立ち上 がり動作を遂行することに関して筋力的問題はない. ただし, 大森ら ${ }^{(9)}$ の高齢入院患に対する調查によると, 起 立不可能者のピークトルク平均值は $0.43 \pm 0.18 \mathrm{Nm} / \mathrm{kg}$ となっているので, Phase 1 のみではなく Phase 2 において膝 関節伸展, 股関節伸展による重心上昇を支援し, 起立に必要な膝関節モーメントを低減する必要がある.

\section{5. 起立時の筋負荷評価}

\section{$5 \cdot 1$ 実験目的}

4 章で開発した起立支援機器のプロトタイプを用いることで, 実際に起立を支援できるかを関節負荷のもと となる筋への負荷（表面筋電信号）の観点から評価することを目的とする.

\section{$5 \cdot 2$ 実験方法}

体型の異なる若年健常者 3 名 (\#1:1.70[m], 62[kg], 27[yrs], \#2:1.84[m], 61[kg], 23[yrs], \#3:1.73[m], 63[kg], 25[yrs]）が起立動作を行い，そのときの筋電信号を計測した。

実験条件は開発した支援機器を用いての起立動作, 何も用いない通常の起立動作をそれぞれ5 試行ずつ行った. また，参考のために平地歩行 10 歩を 5 試行行った。起立動作時の膝関節への負担は足の位置の位置に大きく影 響を受ける. 本研究では, 最も基本的な状態として, 膝関節の鉛直下方に足関節がくる（すなわち Phase 0 の座 面高さ調節により膝角度が 90deg になる）ように足を位置するように被験者に指示した。一方，手に関しては特 に指示をしなかった。

図 8 に示したように筋電信号はそれぞれの試行において起立動作に関与が深いと考えられる左右の前頸骨筋

（TA: Tibialis Anterior，足関節の背屈に大きく関与する下腿全面の筋），大腿直筋（RF: Rectus Femoris，膝関節お よび股関節の伸展に大きく関与する上腿全面の筋), 春柱起立筋（ES: Erector Spinae，体幹の伸展に大きく関与す る体幹背面の筋)の計 6 箇所に能動電極（バイオメトリクス社, 塩化銅, 電極間距離 : $20[\mathrm{~mm}]$, サンプリング周 波数 : $1000[\mathrm{~Hz}]$, 入力インピーダンス: $10^{15}[\Omega]$ ) を貼付し計測し, データロガー（バイオメトリクス社，サンプリ ング周波数 : $1000[\mathrm{~Hz}]$ ）に記録した. また，不感電極は右足腓骨下端に貼付した．ただし，電極位置は神経支配 帯を挟んでいないことを確認した.

筋負荷の評価指標としては，積分筋電位 $(i E M G)$ とした．積分筋電位は，式（2）で表されるように起立動作 時における筋電信号の振幅の絶対值の和を起立動作時間で除したもので, 筋出力と筋振幅に比例的な関係がある 

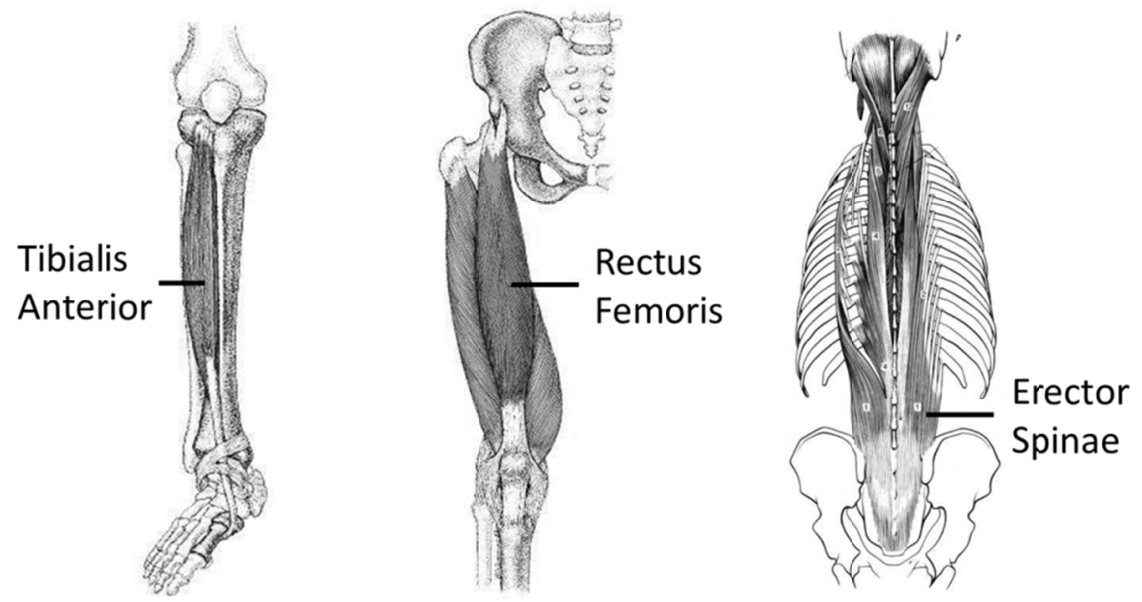

Fig. 8 EMG-measured muscles

ことから，最も一般的な筋負荷を評価する指標として用いられている.

$$
i E M G=\sum_{t=T_{\text {start }}}^{T_{\text {end }}}\|\operatorname{emg}(t)\| /\left(T_{\text {end }}-T_{\text {start }}\right)
$$

ただし， emg $(t)$ は時刻 $t$ における筋電信号の振幅を表し， $T_{\text {start }}$ を起立動作開始時刻， $T_{\text {end }}$ を起立動作終了時刻とし た．開始時刻と終了時刻は被験者が把持している ON・OFF スイッチにより判定した。

また，筋電信号は被験者，電極位置，皮膚状態などによって得られる振幅值に大きな差が出るために，前頸骨 筋, 大腿直筋, 脊柱起立筋の最大随意収縮 (Maximum Voluntary Contraction: MVC) 時の筋電信号を計測し, 式 ( 1 ) より得られた起立動作時の積分筋電位 $i E M G$ を最大随意収縮時の積分筋電位 $i E M G に よ り$ 正規化した積分筋電位 率 $i E M G \% M V C$ を算出した。 ただし，最大随意収縮の筋電信号は，被験者が椅子に着座し，足関節を固定した条 件で足関節を 3 秒間最大限に背屈させたときの前頸骨筋，体幹を椅子と地面に固定した条件で最大の力で 3 秒間 起立しようとしたときの大腿直筋および 3 秒間背中を背面に押しつけたときの脊柱起立筋から計測した.

なお，各被験者に対しては，実験前にインフォームド・コンセントを得た.

統計解析の項目は，前頸骨筋，大腿直筋，脊柱起立筋それぞれに関して，3つの条件（機器による支援起立， 支援なし起立, 歩行）の積分筋電位率において, 繰り返し要因のある分散分析（ANOVA with repeated measures） 実施後に，3つの条件要因の主効果を Bonferroni 法により多重比較した. また，有意水淮を $\mathrm{p}<0.05$, 信頼区間を 95\%とし，両側検定とした。

\section{$5 \cdot 3$ 実験結果}

図 9(a)，(b)に支援機器を用いた起立動作時，用いなかったときの起立動作時の前頸骨筋，大腿直筋，脊柱起立 筋の整流化した筋電信号の一例をそれぞれ示した，どちらの場合にも，体幹前傾時に前頸骨筋が活動し，その後 重心を持ち上げるときに，大腿直筋および春柱起立筋が活発に発火していることが確認できる.

また，積分筋電位（iEMG\%MVC）に関する結果を図 10 に示した，平均墂準偏差で示すと，前頸骨筋に関し

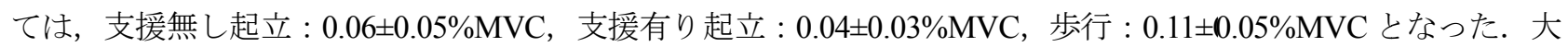
腿直筋に関しては，支援無し起立： $0.27 \pm 0.12 \% \mathrm{MVC}$, 支援有り起立 : $0.15 \pm 0.12 \% \mathrm{MVC}$, 歩行 : $0.17 \pm 0.16 \% \mathrm{MVC}$ となった。 脊柱起立筋に関しては, 支援無し起立： $0.61 \pm 0.18 \% \mathrm{MVC}$, 支援有り起立 : $0.34 \pm 0.19 \% \mathrm{MVC}$, 歩行 : $0.31 \pm 0.05 \% \mathrm{MVC}$ となった.

統計処理においては，大腿直筋における支援有り起立と歩行の間および脊柱起立筋における支援有り起立と歩 行の間以外では，有意差を確認することができた。 

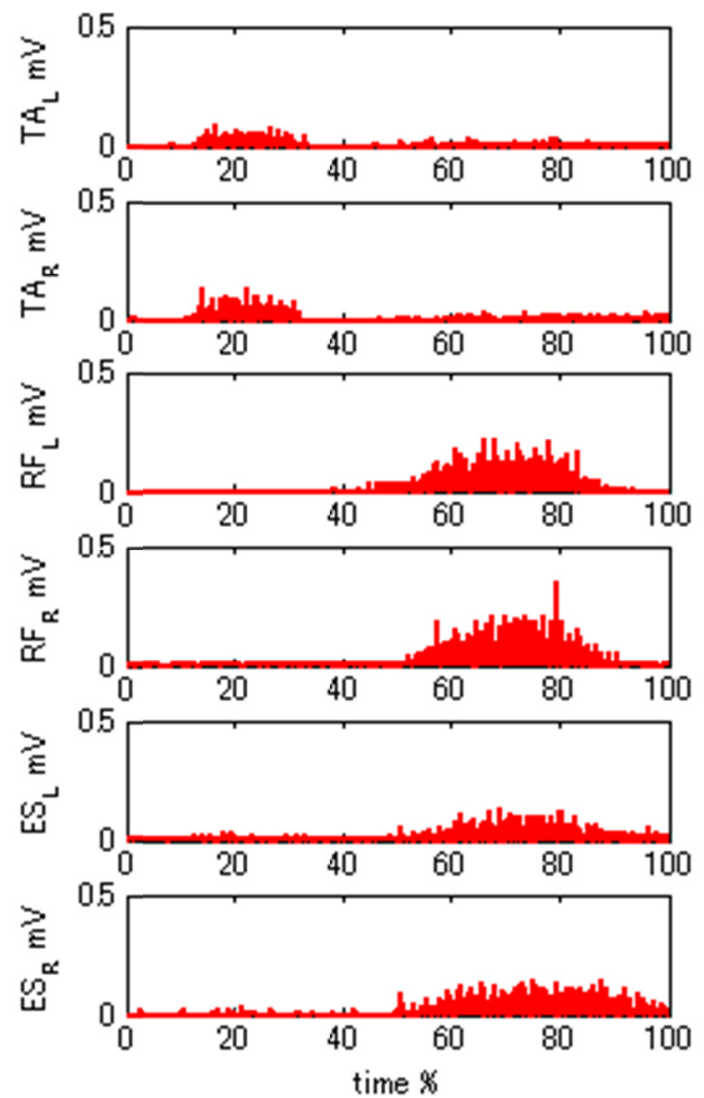

(a) Standing using assist robot
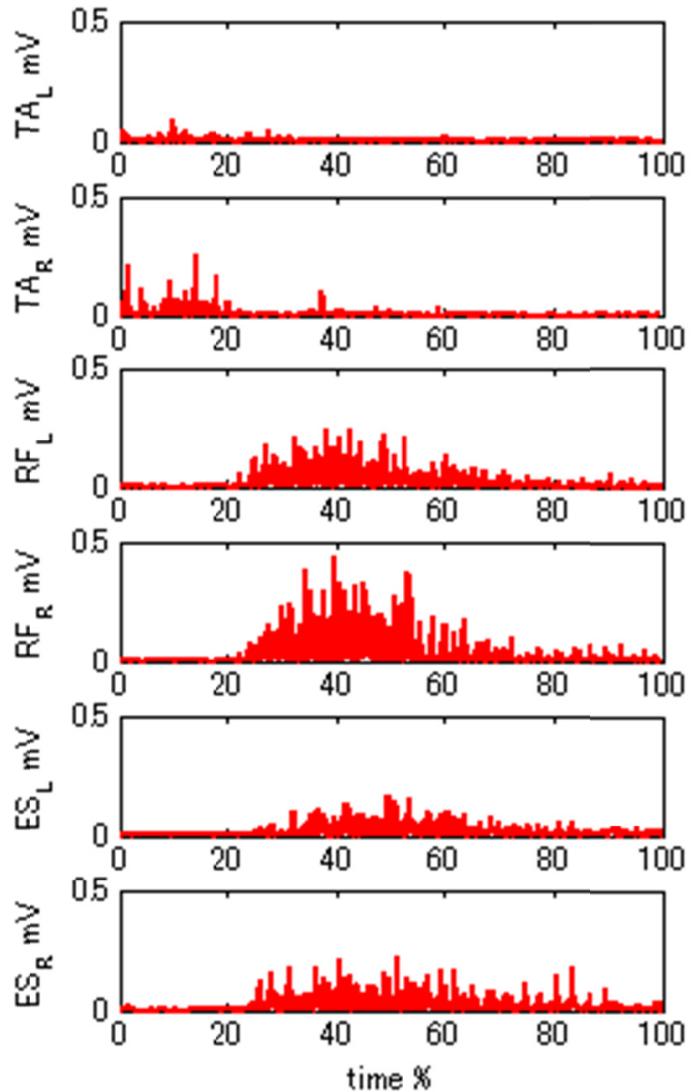

(b) Standing without using assist robot

Fig. 9 Myoelectric signals of left and right TA, RF and ES muscles. Note that time is normalized by standing time.
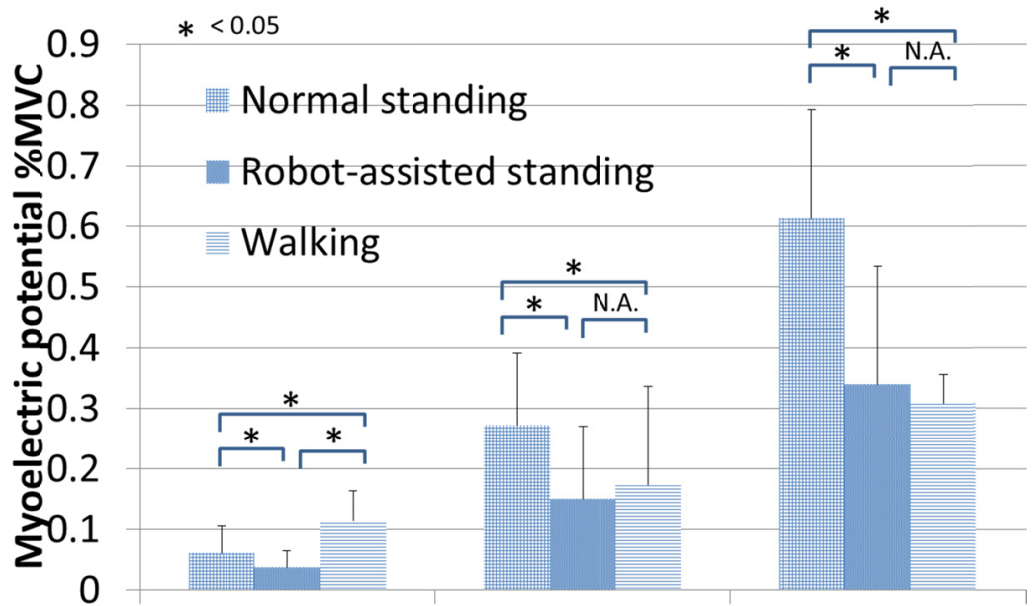

TA

$\mathrm{RF}$

ES

Fig. $10 \mathrm{iEMG}$ of TA, RF and ES muscles. Note that iEMG is normalized by iEMG in maximum voluntary movement (MVC).

\section{$5 \cdot 4$ 実験考察}

前頸骨筋に関しては，支援機器を使うことにより筋負担が約 $2 / 3$ に減少している．また，歩行時の負荷が最 大となっており，支援機器を使った場合，その約 $1 / 3$ となっている. 本研究では歩行が可能な高齢者を対象と しており，歩行より低負荷となっているので，足関節の筋負荷の観点からは起立動作が可能であるといえる．た だし，大森らは立ち上がりの可否に関わる能力として，下肢筋力 ${ }^{(5)}$ 以外にも足関節背屈可動域 ${ }^{(19)}$ があると指摘し ている. よって, 本機器の適応対象をより詳細に検討する際には, 動力学的な制約条件である筋力に加え, 運動 学的な制約条件である足関節背屈可動域についても考慮する必要がある. 
大腿直筋に関しては，支援機器を使うことにより筋負荷が約 $1 / 2$ に減少している．また，支援機器を用いた 起立動作と歩行動作の負荷が同程度になっていることから, 対象とする歩行可能群に対して, 達成可能な適切な 負荷を掛けることができていることがわかる．これは機器が全面的に支援するのではなく，あくまでも自発的に 起立動作を遂行しなければいけないことを示しており, 廃用症候群（過度な安静など日常生活の活動量が低下に より, 骨の脆弱化, 心肺機能の低下, 裖瘡, 痴呆や抑うつなど精神症状に繋がり, 寝たきりのおおきな原因とさ れている）などを防ぐ点からも有益である.

脊柱起立筋に関しても，支援機器を使うことにより筋負荷が約 $1 / 2$ に減少している. 大腿直筋と同様に支援 機器を用いた起立動作と歩行動作の負荷に有意差がないことから, 対象と寸る歩行可能群に対して, 達成可能な 適切な負荷を掛けることができていることがわかる. また, 脊柱起立筋の\%MVC の值自体が他の 2 つの筋と比較 すると大きくなっているが，以下の 2 つの理由が考えられる.（1）起立動作は体幹の前傾を伴い, 体重の約半分 という重い物体の前傾姿勢保持を春柱起立筋が主として実現しなければならないという理由である. (2) 本研究 では，MVCを簡易的に計測するために座位で背中を押しつける動作を行ったが，この動作が最大随意収縮運動 ではなかったかもしれないという理由である. 後者に関しては, 本実験では\%MVC の值そのものが重要なので はなく，あくまでも機器支援の有無での起立動作および歩行動作時の筋負荷の関係を検討することが重要である ので，簡易的な本手法でも問題はないが，今後正確な\%MVC 值を算出寸る場合には計測手法を検討する必要が ある.

さらに, 起立動作時の他の筋電研究と比較を行う. 森ら ${ }^{(20)}$ の高齢者を対象とした研究によると, 前頸骨筋に関 しては, $45 \mathrm{~cm}$ 起立可能群 : $20 \% \mathrm{MVC}, 35 \mathrm{~cm}$ 起立可能群 : $30 \% \mathrm{MVC}, 25 \mathrm{~cm}$ 起立可能群 : $40 \% \mathrm{MVC}$ となり, 大 腿直筋に関しては， $45 \mathrm{~cm}$ 起立可能群 : $18 \% \mathrm{MVC}, 35 \mathrm{~cm}$ 起立可能群 : $23 \% \mathrm{MVC}, 25 \mathrm{~cm}$ 起立可能群 : $35 \% \mathrm{MVC}$ となっている. また，若年者の起立（座面高： $45 \mathrm{~cm}$ ）時の筋活動（前脛骨筋 : $23 \% \mathrm{MVC}$, 大腿直筋: $14 \% \mathrm{MVC}$, ) となっている(21). 大腿直筋に関しては, 先行研究と同程度の值が算出されているが, 前頸骨筋に関しては, 本研 究の\%MVC 值と差異が生じており，これは春柱起立筋と同じ理由であると考えられる．上記の先行研究より， 膝伸展に関わる筋群では\%MVC の值にそれほど差がないことがわかり, さらに高齢者と若年者では最大随意収 縮 MVC（大腿直筋，大腿二頭筋，前脛骨筋，腓腹筋）には有意差がないという報告(22,23)を考慮すると，本研究 では若年者を被験者として実験を行ったが，高齢者が使用したときにおいても筋負担が減少するという同様の結 果が得られることが予想される，ただし，高齢者では平衡保持のために拮抗筋が総動員されるため(24)，高齢者の 起立動作実験時には拮抗筋の活動も計測する必要がある. また, 筋発火のタイミングについて考察すると, 文献 (25)などによると, 高齢者の起立動作において ES が RF に先行して活動を開始するとの知見も報告されているが, 本研究では確認できなかった. ES が先行する主な要因は前傾姿勢の保持であり, 本研究において被験者には高齢 者に多い加速的動作を伴わない（前傾保持を必要とする）静的起立をするように指示したが, 動的に近い起立動 作となり，下肢筋群を主に利用して起立したためであると考えられる.

\section{6. 結 語}

本研究では, 在宅や病院などにおける高齢者のベッドからの起立動作を支援する機器の提案およびプロトタイ プの開発を行った．特に，室内で歩行動作が可能であるにもかかわらず，下肢筋力不足のために起立動作が遂行 できない高齢者を対象とし, ベッド周りの空間を阻害せず, 既存の電動ベッドに後付けが可能であることを最大 の特徵とする機器の提案・開発を行い，実際の頻繁に用いられている電動べッドに設置可能であることを確認し た. 開発した起立支援システムは，3 自由度を有しており，まず体幹前傾を促した上で，次に残存機能を活用し ながら重心を上昇させる制御を行うこととした．健常者が開発した起立支援システムを用いて起立動作を行った 際の, 下肢の主要筋群への負荷を筋電信号から解析したところ, 支援機器を用いることにより, 用いなかったと きの負荷と比較すると， 1 / 2 2 $/ 3$ 程度に減少していることが確認できた. さらに，大腿直筋と春柱起立筋 に関しては, 歩行時の負荷と同程度となっており, 対象としている歩行可能であるが起立不可能な高齢者にとっ て, 適切な負荷であることが示唆された. これにより提案・開発したベッド後付け可能な起立支援機器のコンセ プトの有用性を確認することができた. 
今後は，多くの電動ベッドに対応できるようにベッド下空間の調査を行い，設計の最適化を行うとともに，膝 関節への負担が小さくなる，もしくは起立しやすいための制御則の確立し，高齢者による実証実験を行うものと する

\section{謝辞}

本研究に協力いただいた被験者の方々に，ここに記して感謝の意を表す。また，機構の設計支援を頂いた有限会 社安久工機田中隆氏，配線作業などを手伝って頂いた大阪大学坂田奈津美氏に，ここに記して感謝の意を表す. 本研究の一部は, 文科省科研費基盤研究 A「全身協調動作を誘発する福祉支援ロボットの制御手法の構築」, がん 臨床研究事業「地域におけるがん患者等社会的支援の効果的な実施に関する研究」の支援を受けて行われた.

\section{文献}

(1) 山田宏尚, 森田啓之, 田中邦彦, 坂東直行, “起立動作特性の解析に基づく起立補助装置の開発”, 日本機械学會論文 集 C 編, Vol. 74, No. 742, (2008), pp.1522-1530

(2) 中後大輔, 高瀬國克, “起立/着座支援機能を有する歩行器の研究”, 福祉工学シンポジウム講演論文集, (2007), pp.44-47

（3）山口亨，“日常支援型知的モビリティロボットの開発”，http://jstshingi.jp/abst/p/09/919/tama4.pdf，(参照日 2011 年 9 月 29 日)

(4) 初雁卓郎，黒子詩穂，三宅徳久，樋口淳一，平田泰久，小菅一弘,”高齢者の特性に適応する起立支援システム”, 日 本機械学会論文集 C 編 ，Vol. 74, No. 740, (2008), pp.186-193

(5) M. A. Hughes, B. S. Myers, M. L. Schenkma, "The role of strength in rising from a chair in the functionally impaired elderly", Journal of Biomechanics, Vol. 29, (1996), pp.1509-1513

(6) Bajd TB, kralj R, "Standing up of a healthy subject and a paraplegic patients", Journal of Biomechanics, Vol. 15, No. 1, (1982), pp.1-10

(7) 武富由雄, ”高齢施設入所者の股関節伸展筋筋力と立ち上がり動作に関する一考察”, 理学療法学, Vol. 19, (1992), p.263

(8) 福田敏幸, 篠塚 敏雄, ”高齢者における立ち上がり運動の効率と筋力及び ADL の関係について”, 理学療法学 Vol. $27,(2000)$, p.286

(9) 大森圭貢，山崎裕司，横山仁志，“立ち上がりの可否と下肢筋力の関係一高齢入院患者における検討一”，総合リ八， Vol. 30 No. 2, (2002), pp.167-171

(10) Pay YC, Roger MW, "Segmental contributions to total body momentum in sit-to-stand", Medicine \& Science in Sports \& Exercise, Vol. 23, No. 2, (1991), pp.225-230

(11) 中谷敏昭, 灘本雅一, 三村寛一, 伊藤稔, ”日本人高齢者の下肢筋力を簡便に評価する 30 秒椅子立ち上がりテスト の妥当性”, 体育學研究, Vol. 47, No. 5, (2002), pp.451-461

(12) 江原義弘，山本澄子, ”立ち上がり動作の分析”, 医歯薬出版株式会社, pp.52-55

(13) 大森圭貢, 横山仁志, 青木詩子, 笠原美千代, 平木幸治, 山崎裕司, 笹益雄, ”高齢患者における等尺性膝伸展筋力 と立ち上がり能力の関連”, 理学療法学, Vol. 31, No. 2, (2004), pp.106-112

（14）大森圭貢, 山崎裕司, 横山仁志, 青木詩子, 笠原美千代, 平木幸治, “高齢入院患者の脚伸展筋力と歩行自立度・歩行 速度の関連”, 理学療法, Vol. 16, No. 11, (1999), pp.913-917

(15) 紙屋克子，”介護の心そして技術”，KTC 中央出版，(2001)，pp.112-145

(16) 社団法人人間生活工学研究センター, “高齢者対応基盤整備事業”, http://www.hql.jp/project/funcdb2000/, (参照日 2011 年 9 月 29 日)

(17) 岡田英孝, 阿江通良, 藤井範久, 森丘保典, “日本人高齢者の身体部分慣性特性”, バイオメカニズム, Vol. 13, (1996), pp.125-139 
(18) 蛭田秀一, 島岡みどり，小林寛道，“高齢者 $(60 \sim 80$ 歳代)の等速性最大筋力：脚伸展・屈曲力および筋持久力”, 体力科学, Vol. 35, (1986), p.481

(19) Schenkman M, Hughes MA, et al., "The relative importance of strength and balance in chai rise by functionally impaired older individuals", Journal of the American Geriatrics Society, Vol. 44, (1996), pp.1441-1446

(20) 森明子, 渡辺進, “立ち上がり動作時における下肢抗重力筋の活動について：表面笳電図を用いて”, 理学療法学, Vol. 27, (2000), p.55

(21) 島田洋一，”立ち上がり動作の解析”，総合リ八，Vol. 27, No. 11, (1999), p.1023-1028

(22) 松垣紀子, 勝田茂, ”下肢の筋力の立ち上がり特性における年齢比較”, 日本運動生理学雑誌 Vol. 2, No. 1, (1995), p.40

（23）横井和美，伊丹君和，藤田きみ总，寄本明，前川直美，竹村節子，下野俊哉，古川公宣，“安全なベッドからの立 ち上がりに関する研究(その 2)：表面筋電図を用いた成人患者の下肢筋力の検討”, 人間看護学研究 1, (2004), pp. $29-37$

(24) Manchester D, Woollacott M, Zederbauer-Hylton N, Marin O. Visual, "Vestibular and somatosensory contributions to balance control in the older adult," Gerontology, (1989), p.44

(25) Millington PJ, Myklebust BM, Shambes GM., Biomechanical analysis of the sit-to-stand motion in elderly persons, Archives of Physical Medicine and Rehabilitation, Vol. 73 No. 7, (1992), pp.609-617 